\title{
Residual insulin secretion in adolescent diabetics after remission
}

\author{
M D HOCKING, P W H RAYNER, AND M NATTRASS \\ Children's Hospital, and Diabetic Clinic, General Hospital, Birmingham
}

SUMMARY Twenty four hour blood glucose profiles were compared in two groups of insulin dependent adolescent diabetic patients who were beyond their initial partial remission phase. In the group with persistent endogenous insulin secretion, blood glucose profiles were significantly lower but the difference was small and not reflected in average 24 hour concentrations of glucose nor glycosylated haemoglobin. Endogenous insulin secretion must be considered in studies of metabolic control after the remission period but the effect on overall glucose control is probably clinically unimportant.

The beneficial effect of endogenous insulin secretion on metabolic control in insulin dependent diabetics has been reported. ${ }^{123}$ Endogenous insulin may improve metabolic control because it is secreted into the portal vein and may therefore lead to improved effect of insulin on the liver. Most studies include insulin dependent patients soon after diagnosis and suggest that secretion has to be of a degree not commonly seen in adolescents after the partial remission phase. We have therefore studied the effect of the endogenous secretion of insulin after the remission phase on 24 hour glucose profiles in adolescent insulin dependent diabetics.

\section{Patients and methods}

The 24 hour metabolic profiles of 28 patients were analysed. Two groups of adolescent insulin dependent diabetics (age range 10-17 years) were compared. All were past their partial remission phase: they did not meet the accepted criteria of an insulin requirement of less than $0.5 \mathrm{U} / \mathrm{kg} / \mathrm{day}$ and minimal or no glycosuria, and all had had diabetes for longer than two years. ${ }^{4}$ The patients were recruited from the clinic and were studied before any special attempt was made to improve control. The 10 patients with the highest $C$ peptide excretion formed group $\mathrm{A}$, and the 10 in whom the least was measured formed group B (table). C peptide was above the detection limit of the assay on a mean of 18 of the possible 20 occasions in group A (range 15-20) but only on a mean of one occasion in group $B$ (range $0-3$ ). Average 24 hour $C$ peptide concentrations in individual patients ranged from $0.42-0.73 \mathrm{nmol} / \mathrm{l}$ in group $\mathrm{A}$ and from $0-0.09 \mathrm{nmol} / \mathrm{l}$ in group $\mathrm{B}$.
All patients were treated with either Velosulin and Insulatard (Nordisk Ltd, Epsom, Surrey) or Actrapid and Monotard (Novo Laboratories Ltd, Basingstoke, Hants) except for one patient who was treated with Semitard and Monotard (Novo Laboratories Ltd). One patient in each group needed only one injection of insulin a day, all the rest having two.

The patients were admitted to a side ward the evening before the study. At 0730 the following day an intravenous Teflon cannula (22G Abbocath, Abbott Ireland Ltd, Sligo, Republic of Ireland) was inserted into a forearm vein. Between samples the cannula was kept patent by flushing with saline (154 $\mathrm{mmol} / \mathrm{l}$ ).

A fasting sample was taken at 0800 following which the usual morning insulin was given at 0810 .

Table Characteristics of both groups of patients studied (means and ranges)

\begin{tabular}{|c|c|c|c|}
\hline Variable & $\underset{(n=10)}{\operatorname{Group}} A$ & $\begin{array}{l}\text { Group } B \\
(n=10)\end{array}$ & p Value \\
\hline Age (years) & $\begin{array}{l}13 \cdot 7 \\
(11 \cdot 7-15 \cdot 5)\end{array}$ & $\begin{array}{l}14 \cdot 3 \\
(12 \cdot 0-17 \cdot 0)\end{array}$ & NS \\
\hline $\begin{array}{l}\text { Duration of diabetes } \\
\text { (years) }\end{array}$ & $\begin{array}{l}5 \cdot 3 \\
(2 \cdot 4-10 \cdot 0)\end{array}$ & $\begin{array}{l}9 \cdot 5 \\
(4 \cdot 6-17 \cdot 3)\end{array}$ & $<0.01$ \\
\hline Insulin dose (U/kg) & $\begin{array}{l}1.09 \\
(0 \cdot 65-1 \cdot 52)\end{array}$ & $\begin{array}{l}1 \cdot 13 \\
(0 \cdot 47-1 \cdot 84)\end{array}$ & NS \\
\hline $\begin{array}{l}\% \text { Total daily dose } \\
\text { taken in morning }\end{array}$ & $\begin{array}{l}66 \\
(49-100)\end{array}$ & $\begin{array}{l}69 \\
(47-100)\end{array}$ & NS \\
\hline $\begin{array}{l}\% \text { Morning dose as } \\
\text { quick acting insulin }\end{array}$ & $\begin{array}{l}41 \\
(16-63)\end{array}$ & $\begin{array}{l}41 \\
(22-56)\end{array}$ & NS \\
\hline $\mathrm{HbA}_{1}(\%)$ & $\begin{array}{l}12 \cdot 8 \\
(10 \cdot 9-14 \cdot 1)\end{array}$ & $\begin{array}{l}13 \cdot 2 \\
(7 \cdot 9-18 \cdot 2)\end{array}$ & NS \\
\hline
\end{tabular}


Breakfast was eaten at 0830 , lunch at 1215 , and dinner at 1815 with snacks at 1030,1530 , and 2130 . Evening insulin was given at 1745 . The diet was selected from a standard menu and had the same carbohydrate content as that prescribed for regular consumption at home. Patients were encouraged to walk about during the day. They were free to move between the floors of the hospital but rested for 10 minutes before blood samples were taken.

Blood was taken hourly on the hour during the day. Between 2200 and 0600 samples were taken every two hours. Finally, a sample was taken for measurement of glycosylated haemoglobin concentration $\left(\mathrm{HbA}_{1}\right)$.

Whole blood (1-2 $\mathrm{ml})$ was mixed with $5 \mathrm{ml}$ of ice cold $5 \%(\mathrm{v} / \mathrm{v})$ perchloric acid (BDH Chemicals Ltd, Poole, England) in a preweighed glass tube and stored at $4^{\circ} \mathrm{C}$. At the end of the study the tubes were reweighed and centrifuged. The perchloric acid extract was separated and stored at $-20^{\circ} \mathrm{C}$ before being analysed. The remainder of the blood was placed in a plastic tube and after clotting serum was separated and stored at $-20^{\circ} \mathrm{C}$ for subsequent measurement of $\mathrm{C}$ peptide secretion. Blood for measurement of $\mathrm{HbA}_{1}$ concentration was collected in a plastic tube containing edetic acid.

Blood glucose concentration was measured in the perchloric acid extract by a continuous flow enzymatic fluorimetric technique. ${ }^{5}$ Serum $C$ peptide secretion was measured by a single antibody radioimmunoassay method using antibody M1230 from a commercially available kit (Novo Research Institute, Bagsvaerd, Copenhagen, Denmark). ${ }^{6}$ The assay was done after precipitation of proinsulin/ insulin antibody complexes using polyethylene glycol. ${ }^{7}$ The limit of detection was $0.025 \mathrm{nmol} / \mathrm{l}$. The interassay coefficient of variation was less than $12 \%$ at a concentration of $0 \cdot 13 \mathrm{nmol} / \mathrm{l}$. Total $\mathrm{HbA}_{1}$ was measured by electroendosmosis (Corning Ltd, Halstead, Essex, England), the normal range in our laboratory being $5 \cdot 5-8 \cdot 7 \%$.

Student's unpaired $t$ test was used to assess the significance of differences in age, duration of diabetes, insulin dose (units $/ \mathrm{kg}$ ), percentage of the dose given in the morning, percentage of the dose given as short acting insulin and $\mathrm{HbA}_{1}$ between the groups. Student's $t$ test was used when we compared fasting glucose concentrations between the groups. For data on the 24 hour profile we used the analysis of variance, the determinants being group and time.

\section{Results}

There were no significant differences between the groups regarding age, total daily insulin intake $(\mathrm{U} / \mathrm{kg})$, or details of insulin regimen (table). The duration of diabetes was significantly longer in group $B$ by a mean of $3 \cdot 2$ years.

Fasting blood glucose concentrations were considerably raised in both groups and slightly higher in group $A$, but not significantly so. The mean (SEM) in group A was $17.5(1.4) \mathrm{mmol} / \mathrm{l}$ and in group B $16.5(1.9) \mathrm{mmol} / \mathrm{l}$. The glucose concentration rose to a peak in the mid morning (fig 1) and then dropped, falling faster and further in group A patients. The greatest difference between the groups was during

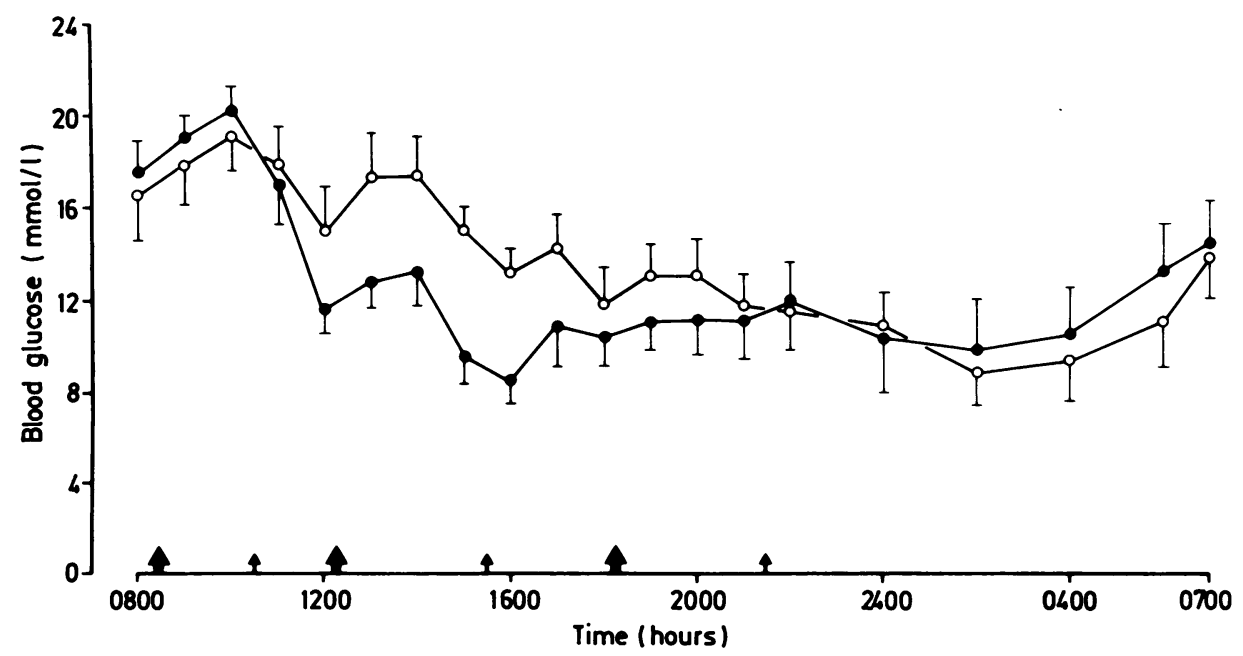

Fig 1 Mean (SEM) 24 hour blood gluc sse profiles in 10 insulin dependent diabetic patients with ((O_ -1$)$ appreciable circulating C pepide. Meals (large arrows) snacks (small arrows). 


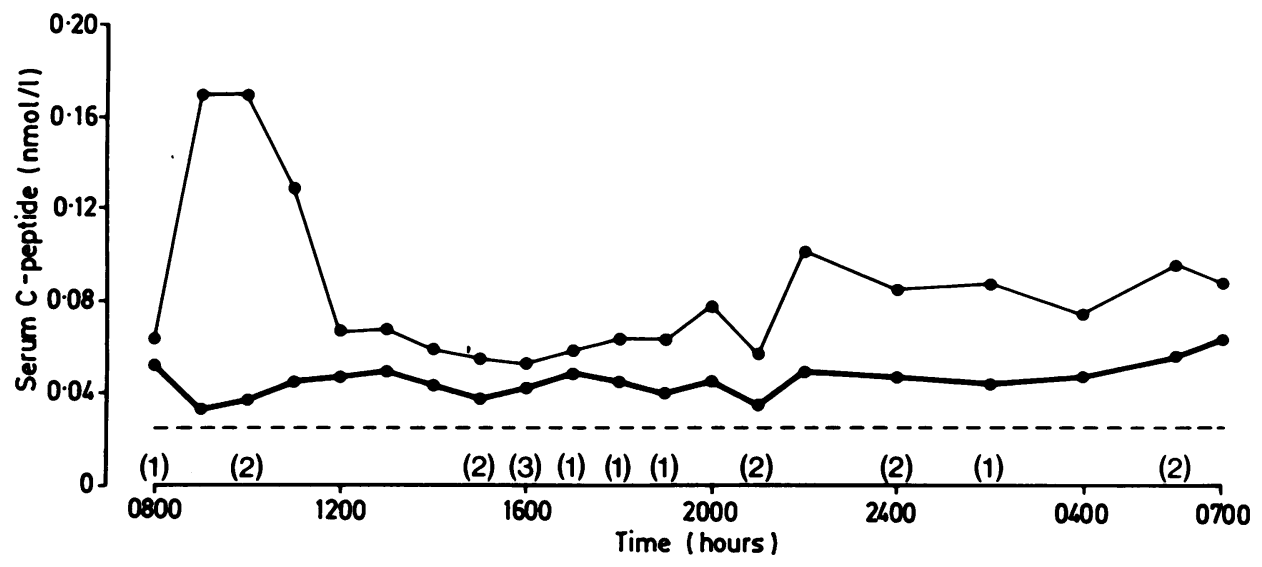

Fig 24 hour $C$ peptide concentration (median -0 ); maximum 10 insulin dependent diabetic patients (group A). Lower limit of detection of assay - - - . No in parentheses refers No of patients with undetectable $C$ peptide at specific times.

the afternoon; there was little difference during the evening and slightly higher concentrations in group $A$ in the middle of the night. The average of the 24 hour mean (SEM) blood glucose profiles was 12.4 $(1.2) \mathrm{mmol} / \mathrm{l}$ in group A and $13.4(1.0) \mathrm{mmol} / \mathrm{l}$ in group B. Group A patients had a small but significantly lower mean blood glucose concentration $(F=3.94, p<0.05)$. Fig 2 shows the maximum and median values of $\mathrm{C}$ peptide concentration in group A.

\section{Discussion}

Residual insulin secretion may be assessed by the C peptide response to tolbutamide, ${ }^{8}$ glucagon, ${ }^{9}$ oral glucose,$^{10}$ or a standard meal. ${ }^{9}$ The importance of residual insulin secretion, however, lies in the effect on blood glucose control during a normal day. We have considered our patients in two groups according to total 24 hour $C$ peptide secretion, although endogenous insulin may be inhibited by low blood glucose concentrations or administration of exogenous insulin. ${ }^{11}$ These effects were probably minimal in the group A patients as insulin secretion is maximally stimulated when blood glucose concentrations are greater than $12 \mathrm{mmol} / \mathrm{l}$, and all patients had concentrations greater than this at some time during the 24 hours.

The degree to which type 1 diabetics can secrete insulin after remission declines gradually with time and it is not surprising therefore that our patients with less $C$ peptide secretion had had the disease longest ${ }^{12}$ although there was no difference in their ages.

Fasting blood glucose concentrations showed equally poor control in both groups at the start of the day. Clearly any help to control given by the small amount of endogenous insulin was of little value and this is a time of difficulty with control. ${ }^{13-15}$ The small but significant effect on blood glucose concentration was most obvious in the afternoon The mechanism of action of endogenous insulin ise most likely to be on the liver as the small amounts? detected are unlikely to raise peripheral insulin significantly, and hepatic production of glucose is more sensitive to insulin than peripheral glucose uptake.

This study shows that endogenous insulin secretion may exert metabolic effects even when present in low amounts. The effect is small and in clinical terms probably irrelevant. It is certainly less important than insulin dose, diet, and exercise. From an investigative viewpoint studies of control should take account of even small amounts of endogenous insulin secretion.

MH was supported by Eli Lilly and we thank Eli Lilly and the Bicentenary Advisory Board of the General Hospital, Birmingham for financial support.

\section{References}

1 Madsbad S, Faber OK, Binder C, Alberti KGMM, Lloyd B. Diurnal profiles of intermediary metabolites in insulin dependent diabetes and their relationship to different degrees of residual beta cell function. Acta Diabetol Lat 1981;18:115-21.

2 Madsbad S, McNair P, Faber OK, Binder C, Christiansen C, Trasbol I. Beta cell function and metabolic control in insulin treated diabetics. Acta Endocrinol (Copenh) 1980;93:196-200.

${ }^{3}$ Ludvigson J, Leding LG, Larsson Y, Leander E. C-peptide in juvenile diabetics beyond the post-initial remission period. Acta Paediatr Scand 1977;66:177-84.

${ }^{4}$ Akerblom HK. Definition of partial remission in insulin- 
dependent, juvenile-onset diabetes mellitus (IDDM). Acta Paediatrica Belgica 1980;33:60.

${ }^{5}$ Lloyd B, Burrin J, Smythe P, Alberti KGMM. Enzymatic fluorimetric continuous-flow assays for blood glucose, lactate, pyruvate, alanine, glycerol and 3-hydroxybutyrate. Clin Chem 1978;24:1724-9.

${ }^{6}$ Heding LG. Radioimmunological determination of human Cpeptide in serum. Diabetologia 1975;11:541-8.

7 Kuzuya H, Blix PM, Horwitz DL, Steiner DF, Rubenstein AH. Determination of free and total insulin and C-peptide in insulin treated diabetics. Diabetes 1977;26:22-9.

${ }^{8}$ Mirel RD, Ginsberg-Fellner F, Horwitz DL, Rayfield EJ. Cpeptide reserve in insulin-dependent diabetics. Diabetologia 1980;19:183-8.

9 Faber OK, Binder C. C-peptide response to glucagon: a test of the residual B-cell function in diabetes mellitus. Diabetes 1977;26:605-10.

${ }^{10}$ Heding LG, Munkgaard Rasmussen S. Human C-peptide in normal and diabetic subjects. Diabetologia 1975;11:201-6.
11 Faber OK. Wahren J, Ferrannini E, Binder C, DeFronzo RA. Direct effect of insulin on the B-cell function. Diabetologia 1978; 15:230.

12 Madsbad S, Faber OK, Binder C, McNair P, Christiansen C, Transbol I. Prevalence of residual beta-cell function in insulindependent diabetics in relation to age at onset and duration of diabetes. Diabetes 1978;27(suppl 1):262-4.

${ }^{13}$ Hocking MD, Rayner PHW. Nattrass M. Metabolic rhythms in adolescents with diabetes. Arch Dis Child 1986;61:124-9.

${ }^{14}$ Hocking MD, Crase J, Rayner PHW, Nattrass M. Metabolic rhythms in adolescents with diabetes during treatment with porcine or human insulin. Arch Dis Child 1986:61:341-5.

15 Alberti KGMM, Dornhorst A, Rowe AS. Metabolic rhythms in normal and diabetic man. Isr J Med Sci 1975:11:571-80.

Correspondence to Dr M Nattrass, General Hospital, Birmingham B4 $6 \mathrm{NH}$.

Reccived 1 June 1987 